\title{
Value-added Product on Coffee Marketing in Pasuruan District
}

\author{
Lya Aklimawati ${ }^{1 *}$ \\ ${ }^{1}$ Indonesian Coffee and Cocoa Research Institute, J1. PB. Sudirman 90, Jember Indonesia \\ ${ }^{*}$ Corresponding author: lya.akli@gmail.com \\ Received: 30 October 2017 / Accepted: 16 November 2017
}

\begin{abstract}
Development of household coffee industry can be used as a strategy to redistribute farmers' household income. Through production process, farmer can create value-added by producing high value commercialized products. The objective of this research were to assess coffee price dynamics in Pasuruan district; and to analyze the value-added of coffee products produced by farmers. This research was carried out in Pasuruan district including Prigen, Tutur, Purwodadi, Purwosari, and Puspo sub-districts. Respondents were selected by using snowball sampling method as much as 16 farmers. Data used in this research preferred primary data with secondary data as a supporting data. Data were analyzed with descriptive analysis, inductive analysis, and Hayami method. The results showed that the average of farmer's share in Robusta coffee sales had exceeded $80 \%$ of the international market and Lampung spot market. Meanwhile, the average of farmer's share in Arabica coffee sales was more than $40 \%$ of the international market and Medan spot market. Higher value-added could be created by conducting downstream processing as one of product diversification activities. Robusta and Arabica coffee which had been marketed as roasted coffee and ground coffee would provide a higher value-added than that of primary products (cherries, dried cherries, green bean). Based on these cases, farmers could gain the highest value-added by marketing ground coffee products.
\end{abstract}

Keywords: Value-added, Hayami method, price, coffee, downstream processing, product diversification

\section{INTRODUCTION}

Coffee is one of plantation commodities that has a role to develop farmer economy. This economic development is intended to empower farmers to carry out economic activities to improve economic conditions of their households. Efforts to mobilize the farmer economy can be done through the growth of local resource-based industries. Development of the industry not only contributes to the increase of farmers' income, but also has an effect of multiplying effect on the growth of other economic sectors (Hadi \& Friyatno, 2008).
In terms of the processing field, industrial activities are "media" to create an added value for the products produced by farmers. The added value is defined as the difference between the output value of the products and the cost value of raw materials and other inputs, excluding labor costs (Hayami et al., 1987). Referring to this understanding, agricultural products will have an added value if the product undergoes further production processes such as processing, storage, packaging and distribution (Suprapto cit. Kustiari, 2012). Hayami et al. (1987) mentioned the added value as one component in the analysis of production structure. It is explained that the main 
production structure analyzes the relationship between input/production factor, output, income and profit in the production process. In this context, the product has an added value after going through a series of production to become an intermediate product or an end product. This concept is also in line with Laufenberg et al. (2003) stating that the transformation of products into new commercial products through advanced processing can increase the added value of the product. Ruauw et al. (2012) revealed that the concept of the added value had a correlation with market demands and consumer preferences. Changes in consumer demand and preference will affect the measure of the product value.

The current conditions in the field showed that farmers were the economic agents who gained the smallest added value and beared the highest production risk. Therefore, the development of agro-industry could be used as an alternative model of community empowerment to increase the added value of products by utilizing local raw materials. Majority of farmers still depended on farming activities in the on-farm subsystem. Farmers often market their products in form of primary products. Only a small percentage of farmers developed business in the field of coffee processing and then sold the products in form of processed products such as roasted coffee and ground coffee. Although the scale of businesses is categorized as household-scale industry, the resulting product is able to enrich the variety of products in the local market and fill the market outside the region (Aklimawati et al., 2016). The processing of the coffee product needs to develop in order to increase the added value of the products and the income of farmers and industry players.

Agro-industry is understood as an activity to increase the added value by diversifying products from primary products. The same as other agricultural products, coffee can be further processed into processed products with higher economic value than the primary products. Processed coffee products have the added value for the industry players because the demand for these products is still quite high. Given that drinking coffee is increasingly entrenched and becomes a part of social life in society (Aklimawati \& Shaf, 2016). On the other hand, the market share of processed coffee products is quite broad and prospective in terms of market segmentation, therefore the household-scale industry has a chance to enter the market. In taking advantages of these market opportunities, the home industry must also be keen in meeting the market demand, especially changes in consumer preferences.

The increase of added value through development of coffee agro-industry had been used by farmers in Pasuruan. Farmers optimize the availability of local resources, in the case of coffee, to be marketed as processed coffee products. Farmers think that the processing activities is one strategy to increase the added value of products, increase income and create jobs for the surrounding community. The prospect of a better coffee business in the future encourages farmers and other economic agents to market coffee products with higher commercial value. This research aimed to study the dynamics of coffee prices in Pasuruan Regency; and to analyze the value-added ratio of coffee products produced by farmers.

\section{MATERIALS AND METHODS}

This research used a descriptive research with qualitative approach aimed to describe the situation or the phenomenon was studied. This research used descriptive data and quantitative data to provide a complete picture of the studied object. This research was conducted by means of survey method (Rianse \& Abdi, 2009). 
This research was conducted in Pasuruan Regency in July 2016. The location was chosen purposively with the consideration that this regency was one of coffee production centers in East Java. Another consideration was that farmers sold coffee in various forms of products including fresh coffee, dried coffee, coffee beans, roasted and ground coffee beans. The research location covered 5 subdistricts, namely Prigen, Tutur, Purwodadi, Purwosari and Puspo Subdistricts.

The research data was collected through direct observation and interviews of selected respondents. The preference of research data and information was direct (first hand) or primary data. Meanwhile, secondary data were used as the support in the primary data analysis. The used research instrument was a questionnaire with several lists of questions. The primary data included information on processing, pricing, processing costs, labor requirements and labor costs. The secondary data were obtained through the search of statistical data issued by relevant agencies.

In this research, the selection of respondents was done by using non-probability sampling approach. The used method was snowball sampling and it avoided random selection. The main research respondents were key informants with the assumption that the respondents were considered most knowledgeable about the studied research topic. Thus, the number of respondents would be limited because it focused more on information owned by respondents (Rianse \& Abdi, 2009). The 16 research respondents as farmers acted as traders or micro-scale business (domestic industry) players.

This research employed descriptive analysis and inductive analysis. Descriptive analysis is employed to describe descriptive data into the form of description or report. The interpretation of these descriptive data described the condition of the research subject or object systematically. Inductive analysis was employed with the consideration that the analysis could bring up a theme or category and showed the relationship pattern between the theme or category. In addition, inductive analysis can describe the research topic completely and can make decisions whether it can be transferred to other topics (Rianse \& Abdi, 2009; Bachri, 2010; Wahyuningtyas, 2011). The analysis of added value on coffee products employed the Hayami method (Hayami et al., 1987). This method has been used in researches conducted by Ruauw et al. (2012); Hasanah et al. (2015); and Hasibuan et al. (2015). The concept of added value calculation with Hayami method is shown in Table 1. In this study, the calculation of added value also included component of production cost, except labor and raw material costs. These production costs are converted into per unit-cost and included in point 9 in the Hayami method (Table 1).

Table 1. Production structure for analyzing value-added product and profit

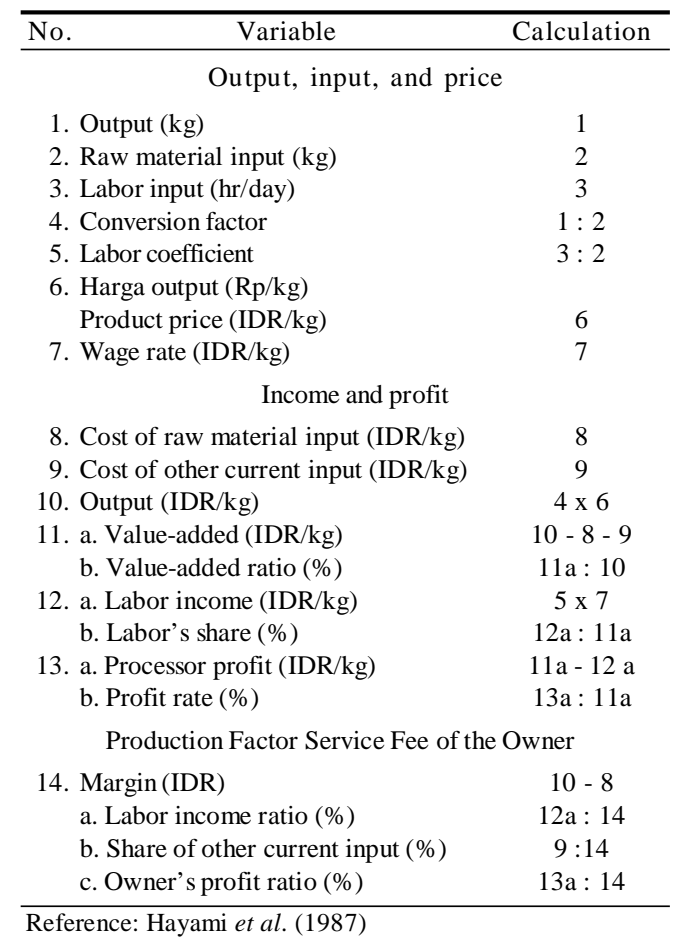




\section{RESULTS AND DISCUSSION}

Farmers in Pasuruan generally developed Robusta coffee and only a small percentage of farmers cultivated Arabica coffee. The yield of coffee production was usually stored in form of dried-coffee cherries by using plastic bags. Farmers assume that dried coffee can be stored for a long period of time and can be used as a stockpile. The sale of coffee depends on the conditions and economic needs of farmers' households. Most farmers marketed coffee in form of primary products such as fresh coffee, dried coffee and coffee beans.

In terms of price, Arabica coffee had a similar price with Robusta coffee. This can be due to the limited knowledge of information and market networks. In addition, the least proportion of Arabica coffee compared with Robusta coffee could be a factor in the absence of price differences. Farmers were often positioned as price takers because the bargaining position of farmers tended to be weaker than traders. Therefore, farmers could not negotiate prices with traders. The results of the coffee price survey at the farmer level are presented in Table 2.

Based on the price positions in Table 2, it is known that fresh-coffee cherries were purchased at relatively low prices if the payment system was made with a ijon (purchasing unpicked yields) system. Farmers sold the coffee charries with the ijon system because of the economic condition for their daily needs. The sale in the form of dried coffee can increase the price of coffee even though the price difference was not too high. By selling dried-coffee cherries, farmers need efforts to do the processing. Most farmers sell coffee in the form of dried coffee and fresh coffee because they believe that the product can still be sold and does not take long time in processing. Only a few farmers do coffee sales in the form of coffee beans. Farmers think that the sale of coffee beans is considered more profitable compared with the sale of fresh coffee and dried coffee. In general, farmers who sold coffee were farmers acted as the management of farmer groups and traders.

The price of Robusta coffee in Pasuruan Regency was higher than the price of Robusta coffee spot in Lampung. However, the price was lower than Robusta coffee in the international market. This condition was in the price section received by farmers or farmer's share. The value of farmer's share for Robusta coffee was about $85.76 \%$ against the price of international coffee and reached $110.28 \%$ against the price of coffee in the spot market of Lampung. On Arabica coffee, the price of coffee beans at farm level was much lower than the price of Arabica coffee in the spot market of Medan and international markets. The value of farmer's share in Arabica coffee sales was $45.27 \%$ against the price of international Arabica coffee and $40.37 \%$ against the price of Arabica coffee in the spot market of Medan, assuming that the marketing cost was not taken into account. It was believed that the low price of Arabica coffee was due to the processing of coffee by dry method (dry process) so that it might impact on the coffee physical and flavor qualities. The limited market network of Arabica coffee in the research location could be one of the causes for the low price. In this case, farmers marketed their Arabica coffee in Robusta coffee market because the market created in Pasuruan was Robusta coffee market. To increase the prices of Arabica and Robusta coffee can be done by improving the processing so that the quality of coffee at the level of farmers is able to increase. 
Table 2. Farm gate prices of Robusta and Arabica coffee in Pasuruan District

\begin{tabular}{|c|c|c|c|}
\hline Form of coffee & Type of coffee & Payment system & Price (IDR/kg) \\
\hline Cherries & Robusta/Arabica & $\begin{array}{c}\text { Cash } \\
\text { Debt bonded }\end{array}$ & $\begin{array}{l}3.500-5.000 \\
3.000\end{array}$ \\
\hline Dried cherries & $\begin{array}{l}\text { Robusta } \\
\text { Arabica }\end{array}$ & $\begin{array}{l}\text { Cash } \\
\text { Cash }\end{array}$ & $\begin{array}{l}11.000-15.000 \\
15.000-18.000\end{array}$ \\
\hline Green bean at farmer level & Robusta/Arabica & Cash & $20.000-25.000$ \\
\hline Green bean at collector level & Arabica & Cash & $24.000-30.000$ \\
\hline Comparison & \multicolumn{3}{|c|}{$\begin{array}{l}\text { a. Robusta coffee of USD2.00/kg green bean or equal IDR26,236/kg green bean (kurs } \\
\text { dollar*** of IDR } 13,118 \text { ) on July } 2016\end{array}$} \\
\hline International Prices* & \multicolumn{3}{|c|}{$\begin{array}{l}\text { b. Arabica coffee of USD } 3.79 / \mathrm{kg} \text { green bean or equal IDR } 49,717 / \mathrm{kg} \text { green bean (kurs dollar**** } \\
\text { of IDR13,118) on July } 2016\end{array}$} \\
\hline $\begin{array}{l}\text { Price at Medan Spot Market** } \\
\text { Price at Lampung Spot Market** }\end{array}$ & \multicolumn{3}{|c|}{$\begin{array}{l}\text { IDR51,500 - 57,000/kg Arabica green beans on July } 2016 \\
\text { IDR16,500 - 21,500/kg Robusta green bean on July } 2016\end{array}$} \\
\hline 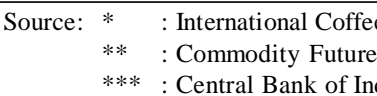 & $\begin{array}{l}\text { Organization } \\
\text { Trading Regulatory Ag } \\
\text { nesia }\end{array}$ & onesia & \\
\hline
\end{tabular}

To increase coffee price can also be pursued by diversification of coffee products into processed coffee products. Farmers have not made use of the opportunity of rising income widely. Only a few farmers or farmer groups produce processed coffee products in form of ground coffee and roasted coffee beans. Diversification of these products is considered very profitable for farmers because it can increase the added value of products and income. The variation in the price of ground coffee and roasted coffee beans at farm level is shown in Table 3. By doing downstream processing, the range of Robusta ground coffee price was from Rp.75,000 to Rp.100,000 per kg while Robusta roasted coffee beans were sold at
Rp.80,000 per kg. Product diversification also increased the price of Arabica coffee. Farmers could sell Arabica ground coffee for Rp.150,000 per kg and roasted coffee beans for Rp.100,000 per $\mathrm{kg}$. The process of blending coffee also increases the commercial value of processed coffee products. The price of blend coffee (Arabica and Robusta) ranged from Rp.120,000 to Rp.150,000 per kg. The added value of processed coffee products had attracted the interest of farmers to develop businesses in the field of downstream processing of coffee. The business scale is still categorized as the household-industry class but it is able to supply the demand for coffee in the local market and outside its region.

Table 3. Price variation of downstream coffee product at farmer level

\begin{tabular}{lrc}
\hline Product & Size of Packaging & Price (IDR) \\
\hline Robusta ground coffee & $250 \mathrm{~g}$ & 25,000 \\
& $100 \mathrm{~g}$ & $7,500-10,000$ \\
Arabica ground coffee & $1,000 \mathrm{~g}$ & 150.000 \\
Ground coffee blending (Arabica and Robusta) & $250 \mathrm{~g}$ & $30,000-37,500$ \\
Robusta roasted coffee beans & $1,000 \mathrm{~g}$ & 80,000 \\
Arabica roasted coffee beans & $1,000 \mathrm{~g}$ & 100,000 \\
\hline
\end{tabular}


Opportunities to add value to coffee products have been exploited by small farmers by doing the processing, they can increase the selling price of the products. In principle, the added value will be gained when the raw materials get the treatment or technology that goes on during the processing to become new products with a higher commercial value (Laufenberg et al., 2003; Ruauw et al., 2012). This research will compare the amount of added value on the sale of coffee products both primary and processed products. In Table 4, it shows that Robusta coffee sales in form of fresh-coffee cherries provide the added value of Rp.3,850 with the value added ratio of $85.56 \%$. The high added value was due to the fact that farmers did not purchase raw materials. In other words, the raw materials came from the harvest of their coffee farms. Labor was considered zero because the picking and transport costs were included in other components of input values.

Based on the calculation, the added value on the sale of dried coffee fruits showed higher yields than the added value on the sale of fresh coffee. The added value of dried coffee fruit sales was Rp.5,586 with the value added ratio of $80.10 \%$. The gain of added value is quite high due to the absence of raw material purchasing and processing treatment. Unlike the sale of coffee seeds, the added value showed lower yields than the added value on the sale of dried coffee. The added value of coffee beans was only Rp.1,635 with the value added ratio of $36.11 \%$. It occured because the cost of processing borne by farmers was high, especially the cost of stripping the husk of dried coffee cherries. Most farmers did not have processing facilities so that they still used processing services.

Farmers had market share of processed coffee products tended to market products such as roasted coffee and ground coffee. The sale of Roasted coffee can create the added value of Rp. 22,538 or $36.63 \%$ of output value. Although farmers buy raw materials, the added value gain of roasted coffee is

Table 4. Production structure of Robusta coffee based on form at sales on farmer's household in Pasuruan District

\begin{tabular}{|c|c|c|c|c|c|c|}
\hline \multirow{2}{*}{\multicolumn{2}{|c|}{$\begin{array}{ll}\text { No. } & \text { Variable } \\
\text { Output, input, and price }\end{array}$}} & \multicolumn{5}{|c|}{ Value (Robusta coffee) } \\
\hline & & Cherries & Dried cherries & Green bean & $\begin{array}{c}\text { Roasted } \\
\text { coffee bean }\end{array}$ & Ground coffee \\
\hline 1 & Output (kg) & 1 & 1 & 1 & 1 & 1 \\
\hline 2 & Raw material input $(\mathrm{kg})$ & 1 & 1.9 & 5 & 1.3 & 1.35 \\
\hline 3 & Labor input (hr/day) & 0.000 & 0.150 & 0.151 & 0.008 & 0.010 \\
\hline 4 & Conversion factor & 1.00 & 0.53 & 0.20 & 0.77 & 0.74 \\
\hline 5 & Labor coefficient & 0.0000 & 0.0789 & 0.0302 & 0.0063 & 0.0073 \\
\hline 6 & Product price (IDR/kg) & 4,500 & 13,250 & 22,500 & 80,000 & 87,500 \\
\hline 7 & Wage rate (IDR/kg) & 0.00 & 525.00 & 577.50 & 568.75 & 691.25 \\
\hline \multicolumn{7}{|c|}{ Income and Profit } \\
\hline 8 & Cost of raw material input (IDR/kg) & 0 & 0 & 0 & 25.000 & 25.000 \\
\hline 9 & Cost of other current input (IDR/kg) & 650 & 1,387 & 2,875 & 14,000 & 16,000 \\
\hline 10 & Output (IDR/kg) & 4,500 & 6,974 & 4,500 & 61,538 & 64,815 \\
\hline \multirow[t]{2}{*}{11} & a. Value-added (IDR/kg) & 3,850 & 5,586 & 1,625 & 22,538 & 23,8145 \\
\hline & b. Value-added ratio (\%) & 85.56 & 80.10 & 36.11 & 36.63 & 36.74 \\
\hline \multirow[t]{2}{*}{12} & a. Labor income (IDR/kg) & 0.000 & 41,447 & 17,412 & 3,555 & 5,056 \\
\hline & b. Labor's share (\%) & 0.000 & 0.742 & 1,071 & 0.016 & 0.021 \\
\hline \multirow[t]{2}{*}{13} & a. Processor profit (IDR/kg) & 3,850 & 5,545 & 1,608 & 22,535 & 23,810 \\
\hline & b. Profit rate $(\%)$ & 85.56 & 79.51 & 35.72 & 36.62 & 36.74 \\
\hline \multicolumn{7}{|c|}{ Production factor service fee of the owner } \\
\hline \multirow[t]{4}{*}{14} & Margin (IDR) & 4,500 & 6,974 & 4,500 & 36,538 & 39,815 \\
\hline & a. Labor income ratio $(\%)$ & 0.000 & 0.594 & 0.387 & 0.010 & 0.013 \\
\hline & b. Share of other current input (\%) & 0.14 & 0.20 & 0.64 & 0.38 & 0.40 \\
\hline & c. Owner's profit ratio $(\%)$ & 85.56 & 79.51 & 35.72 & 61.67 & 59.80 \\
\hline
\end{tabular}


quite high. The creation of high added value can also be gained if the farmers process coffee into ground coffee. It can be seen that the added value of ground coffee sale is $\mathrm{Rp} 23,814$ or $36.74 \%$ of the output value. The value added ratio of roasted coffee beans and ground coffee was lower than the value added ratio on the sales of fresh coffee and dried coffee beans, because the output value in processed coffee products was higher than the one in primary products. By looking at the gain of added value, farmers will get higher profits if they are able to expand their businesses towards the downstream processing of coffee. This processing not only increased their income but also provide employment opportunities for their surrounding communities.

In relation to Arabica coffee, every sold coffee product has a different added value. Table 5 shows that the highest added value is shown by the coffee sale in form of processed products, especially ground coffee. Meanwhile, the lowest added value gained by farmers occured when the coffee product was sold in form of fresh coffee. Sales of Arabica coffee in form of fresh coffee cherries can only create added value of Rp350 with the value added ratio of $5.38 \%$. This added value is considered low because the added value is derived from part of the marketing margin. It appeared that farmers bought fresh coffee cherries from other farmers and sold it back to other buyers.

By doing the drying process, the added value gained became $\mathrm{Rp} 1,514$ or $38.36 \%$ from the output value. Through the drying treatment, the added value of the product might increase. The added value of dried coffee for Arabica coffee was lower than Robusta coffee's added value. It occured due to the need for raw materials in Arabica coffee processing which was more than Robusta coffee processing. The value added ratio of coffee beans showed a value which was smaller than the added value of dried coffee beans. The added value created for the sale of coffee seeds was $\mathrm{Rp} 7,475$ or $26.23 \%$ of the output value. Farmers traded coffee beans gained added value and higher marketing margins. In addition, production cost expenditure could be minimized so that the profit received by farmers was able to be increased.

By means of product diversification, the added value of Arabica coffee became higher than its primary products. Based on Table 5 , the activities of coffee downstream processing could create an added value so that roasted coffee beans and grounded coffee products had a higher product value. The analysis result of the added value showed that the added value of roasted coffee was Rp34,423 with the value added ratio of $44.75 \%$. Meanwhile, the marketing of coffee in the form of ground coffee could produce a higher added value than roasted coffee. The added value of ground coffee could reach Rp.66,611 or $59.95 \%$ of the output value. Although raw materials were bought from other farmers, the added value of roasted coffee and ground coffee was still high. Thus, the farmers conducted processing could generate high profits by marketing their processed coffee products.

The high added value gained from processed products and made from coffee was an opportunity that could be used by farmers to increase their income. Farmers could be encouraged to perform downstream processing, considering that the downstream processing of coffee was relatively simple compared to the one of other plantation commodities. This processing technology can be adopted by farmers to develop coffee businesses. Farmers can process coffee into intermediate products (roasted coffee beans) and end products (ground coffee) which are ready for consumption. Roasted coffee beans can be supplied to coffee shops as raw materials. Through the development of coffee agro-industry, the added value 
Table 5. Production structure of Arabica coffee based on form at sales on farmer's household in Pasuruan District

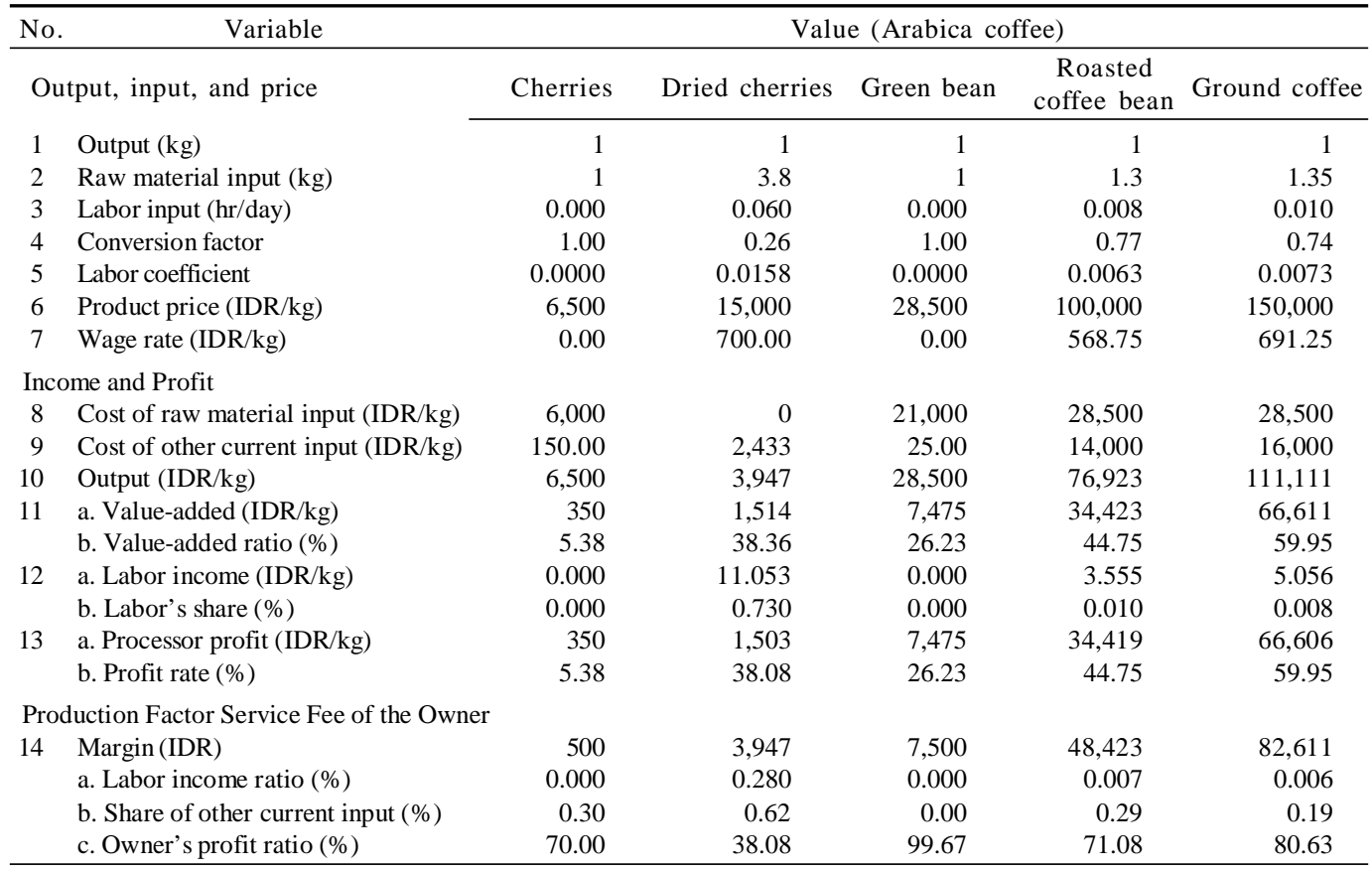

of products could benefit the large-scale coffee industry as well as part of the added value could also be distributed to farmers.

\section{CONCLUSIONS}

Farmer's share in the sale of Robusta coffee exceeds $80 \%$ of the international market and the spot market of Lampung while farmer's share in the sale of Arabica coffee is more than $40 \%$ of the international market and the spot market of Medan. Diversification of coffee products by means of downstream processing can provide a higher added value. The marketing of Robusta and Arabica coffee in the form of processed coffee products (roasted coffee and ground coffee) is able to provide a higher added value than the marketing of its primary products (fresh coffee, dried coffee, and coffee beans). Farmers can gain the highest added value by marketing ground coffee products.

\section{ACKNOWLEDGEMENT}

The researcher would like to thank the Department of Plantation and Forestry of Pasuruan Regency for funding the execution of this study; and Head Coffee Research Center of ICCRI (Dr. Sukrisno Widyotomo, S.TP., M.Si.); and to Dr. Ir. Retno Hulupi, SU. and Ir. Sugiyono for their contribution in assisting the survey activities.

\section{REFERENCES}

Aklimawati, L.; D. Soemarno \& S. Mawardi (2016). Application of marketing mix in home industry: focussed on micro and small scale coffee industry. Pelita Perkebunan, 32, 52-66.

Aklimawati, L. \& W.A. Shaf (2016). Sejumlah nilai dibalik harumnya secangkir kopi. Warta Pusat Penelitian Kopi dan Kakao Indonesia, 28, 29-33.

Bachri, B.S. (2010). Meyakinkan validitas data melalui triangulasi pada penelitian 
kualitatif. Jurnal Teknologi Pendidikan, $10,46-62$.

Hadi, P.U. \& S. Friyatno (2008). Peranan sektor tembakau dan industri rokok dalam perekonomian Indonesia: Analisis Tabel I-O Tahun 2000. Jurnal Agro Ekonomi, 26, 90-121.

Hasanah, U.; Masyhuri \& Djuwari (2015). Analisis nilai tambah agroindustri sale pisang di Kabupaten Kebumen. Ilmu Pertanian, 18, 141-149.

Hasibuan, A.M.; A. Wahyudi; D. Listyati; A. Aunillah; Ermiati \& M. Herman (2015). Peran organisasi petani dalam mengoptimalkan kinerja rantai pasok dan pembentukan nilai tambah kakao: Studi kasus di Kabupaten Kolaka, Sulawesi Tenggara. Jurnal Tanaman Industri dan Penyegar, 2, 1-12.

Hayami, Y.; T. Kawagoe; Y. Morooka \& M. Siregar (1987). Agricultural Marketing and Processing in Upland Java: A Perspective from a Sunda Village. CGPRT No. 8. The CGPRT Centre. Bogor, Indonesia.
Kustiari, R. (2012). Analisis nilai tambah dan imbalan jasa faktor produsi pengolahan hasil pertanian. Prosiding Seminar Nasional "Petani dan Pembangunan Pertanian”, p. 75-85. Pusat Sosial Ekonomi dan Kebijakan Pertanian, Bogor, Indonesia.

Laufenberg, G.; B. Kunz \& M. Nystroem (2003). Transformation of vegetable waste into value added products: (A) the upgrading concept; (B) practical implementations. Bioresource Technology, 87, 167-198.

Rianse, U. \& Abdi (2009). Metodologi Penelitian Sosial dan Ekonomi: Teori dan Aplikasi. Bandung: Alfabeta.

Ruauw, E.; T.M. Katiandagho \& P.A.P. Suwardi (2012). Analisis keuntungan dan nilai tambah agriindustri manisan pala UD Putri di Kota Bitung. ASE, 8, 31-44.

Wahyuningtyas, B.P. (2011). Monas sebagai wajah dewasa Kota Jakarta: Analisis manajemen reputasi dalam pengelolaan Monas sebagai ikon negara. HUMANIORA, $2,123-134$.

$$
* * 0 * *
$$


Aklimawati 